способа преступления в системе элементов криминалистической характеристики преступлений в сфере экономической деятельности и значении такого подхода для модернизачии и соверменствования методик расследования.

Ключевые слова: криминалистическая характеристика преступлений в сфере экономической деятельности, способ преступления, криминалистические признаки преступления.

\title{
CRIME METHOD IN THE SPHERE OF ECONOMIC ACTIVITY AS SYSTEM-FORMING ELEMENT OF CRIMINALISTICS DESCRIPTION
}

\section{Dudnikov A. L.}

The problem questions of criminalistic interrelations of the crime method in sphere of economic activities with other elements of criminalistic characteristic (a subject of a criminal infringement, personality of a criminal, typical traces) are studied. Depending on circumstances, key value when investigating crimes in the sphere of economic activity may have any from the specified elements of the criminalistic characterictics. The analysis of investigative and judicial practice shows that there exist correlation dependences between such structural elements of a criminalistic characteristic of crimes in the sphere of economic activity as their method, typical traces and criminal personalities because the type and the method of a crime are in a close relation with the criminal personality. But as this research and investigative practice proves, for this type of crimes the method occupies a special, leading position. It's a system-forming element of a criminalistic characteristic which is related with the other dependences of high degree of probability. It's explained by that a method is most informative, and in it (by means of it) all components of process of preparation, fulfilment and crime concealment in the sphere of economic activity are fully displayed. The crimes methods study is a source for the newest recommendations on struggle against crime. The data about this criminalistic category is used for working out tactical means and methodical recommendations about disclosure, investigation and the prevention of crimes in the sphere of economic activity and also for the organization and planning of investigation. In particular, the information about the methods of crimes is used for providing comprehensiveness, all-roundness and efficiency of investigation; for search of the persons who have committed a crime, and also for the prevention from their committing by already known methods or by such that could appear.

Keywords: criminalistic characteristic of crimes in the sphere of economic activity, method of crime, criminalistics signs of crime.

УДК 343.98

A. В. Ватраль, докторант відділу аспірантури і докторантури Національної академії Служби безпеки України, кандидат юридичних наук

\section{ЗАСОБИ КРИМІНАЛЬНО-ПРОЦЕСУАЛЬНОГО ПІЗНАННЯ}

Розглянуто основні засоби пізнавальної діяльності слідчого в ході досудового розслідування злочину. Визначено роль слідчих (розщукових), негласних слідчих (розшукових) дій, криміналістичної техніки та заздалегідь

C Ватраль А. В., 2017 
ідентифікованих (помічених), несправжніх (імітаційних) засобів у процесі отримання доказової інформачії для встановлення істини в кримінальному провадженні.

Ключові слова: кримінально-прочесуальне пізнання, доказування, слідчі (розшукові) діï, негласні слідчі (розшукові) діï, криміналістична техніка, заздалегідь ідентифіковані (помічені) засоби, несправжні (імітаційні) засоби.

Кримінально-процесуальна діяльність є одним із видів соціальної діяльності людини й має пізнавальний характер. Органи досудового розслідування 3 метою прийняття правильних і обгрунтованих рішень у ході розслідування обставин учиненого злочину намагаються відновити достовірну картину минулої події, пізнати всі ії обставини й факти, установити істину. Для отримання необхідної інформації про фактичні обставини злочину суб'єкт пізнання має володіти відповідним арсеналом засобів, методів і прийомів.

Не викликає сумніву, що позитивний результат пізнавальної діяльності залежить не тільки від соціальної позиції та компетентності його суб'єктів, але й від того, які ними застосовуються засоби пізнання. Без урахування засобів пізнання не можна правильно оцінити надійність знання в будь-якому пізнавальному процесі. Так, у кримінально-процесуальній діяльності для розширення й поглиблення пізнавальних можливостей слідчого використовуються криміналістичні засоби, які гарантують за правильного їх застосування, отримання необхідної інформації для встановлення об'єктивної дійсності й досягнення істини в справі. У зв'язку з викладеним постає необхідність дослідження засобів кримінально-процесуального пізнання, визначення їх ролі в з'ясуванні фактичних обставин злочину.

Проблеми кримінально-процесуального пізнання, у тому числі засобів, що використовує слідчий у ході пізнавальної діяльності, досліджували такі вчені, як Т. В. Авер'янова, В. П. Бахін, Р. С. Бєлкін, В. В. Бірюков, І. В. Гора, А. В. Іщенко, В. А. Колесник, В. Г. Коломацький, І. І. Котюк, В. В. Лисенко, В. К. Лисиченко, І. М. Лузгін, В. В. Матвієнко, В. О. Образцов, К. С. Поджаренко, I. І. Попович, М. В. Салтевський, В. М. Стратонов, С. А. Шейфер, В. Ю. Шепітько, М. П. Яблоков та інші фахівці в галузі кримінального, кримінально-процесуального права та криміналістики. Проте й сьогодні питання стосовно засобів кримінально-процесуального пізнання $\epsilon$ актуальними як для науки, так і для практики.

Метою статті $\epsilon$ визначення ролі засобів кримінально-процесуальної пізнавальної діяльності у встановленні уповноваженим суб'єктом фактичних обставин учиненого злочину.

Пізнання як філософська категорія - це діяльність людини, метою якої $€$ отримання нового знання. Пізнання здійснюється на основі відображення дійсності у свідомості людини, яке несе інформацію про світ і перетворює iii в знання, тобто стійку систему уявлення про всесвіт ${ }^{1}$. Як досудове роз-

${ }_{1}$ Некрасов С. И., Некрасова Н. А. Философия науки и техники: тематический словарь-справочник: учеб. пособие. Орел: ОГУ, 2010. С. 10. 
слідування, так і судовий розгляд є процесом пізнання, спрямованим на встановлення наявності та обставин учинення кримінального правопорушення й прийняття на цій основі обгрунтованого рішення про притягнення винної особи до відповідальності за вчинений злочин ${ }^{1}$. Інакше кажучи, кримінально-процесуальне пізнання - це процес формування уповноваженим суб'єктом (слідчим) знання про фактичні обставини вчиненого злочину, шляхом отримання за допомогою розроблених наукою криміналістикою спеціальних засобів, методів і прийомів необхідної інформації, їі аналізу та оцінювання з метою встановлення істини в кримінальному провадженні.

У правовій літературі сформувалася думка про те, що пізнання обставин злочину, на відміну від інших видів пізнавальної діяльності людини, відбувається в специфічній формі доказування, яке за своєю гносеологічною сутністю має пізнавальний характер. Водночас у кримінально-процесуальній науці зустрічаються спроби розмежувати поняття «пізнання» й «доказування». Деякі науковці вважають їх якісно різними формами, що здійснюються одним суб’єктом розслідування, однак послідовно змінюють одна одну. Так, на думку I. М. Лузгіна, пізнання в широкому значенні $є$ процесом отримання знань про конкретні предмети або явища, а доказування - це обгрунтування певних положень, створення умов для пізнання тих самих об'єктів іншими особамиㄹ․ Зазначене дає підстави припускати, що спочатку слідчий пізнає обставини злочину, а після цього здійснює доказування. В. С. Джатиєв також відмічає, що пізнання й доказування - різні види раціональної діяльності. Пізнання - це діяльність «для себе», а доказування - «для адресата». Метою пізнання є отримання знання, а метою доказування - переконання адресата в будь-чому․․

Ураховуючи зазначені наукові погляди, слід відмітити, що гносеологія за своєю сутністю й природою не може не зважати на вимоги діалектики, їі принципи, закони та категорії, які екстраполюються й на процес пізнання. Співвідношення пізнання й доказування, що розглядаються в кримінальному процесі як відокремлені в часі операції, які змінюють одна одну, не відповідають реальному стану речей і вихідним положенням гносеології. Тому вважаємо, що пізнання й доказування є майже тотожними поняттями. Пізнання містить усі складові елементи доказування, крім засвідчувального моменту. При цьому всі посадові особи, які здійснюють пізнавальну діяльність у кримінальному процесі, перетворюють «факти для себе» у «факти для всіх».

3'ясувавши, що кримінально-процесуальне пізнання відбувається у формі доказування, постає запитання: як відбувається процес збирання, аналізу

${ }^{1}$ Котюк I. I. Слідчі дії як засіб розв'язання пізнавальних завдань у сфері судочинства. Вісник Акад. адвокатури Украӥни. 2009. № 2(15). С. 15.

2 Лузгин И. М. Расследование как процесс познания: учеб. пособие. М.: Высш. шк. МВД СССР, 1969. С. 21-22.

3 Джатиев B. C. Общая методология и современные проблемы обвинения и защиты по уголовным делам: автореф. дис. ... д-ра юрид. наук: спец. 12.00.09 «Уголовный процесс, криминалистика и судебная экспертиза; оперативно-розыскная деятельность». Владикавказ, 1995. С. 5. 
й оцінювання доказів? Зазначений процес здійснюється за допомогою криміналістичних засобів, які й виконують роль засобів пізнання. У загальноприйнятому розумінні «засіб» - це якась спеціальна дія, що дає можливість здійснити що-небудь, досягти чогось; спосіб; те, що слугує знаряддям у якій-небудь дії, справі. У тлумачному словнику С. І. Ожегова засіб визначається як прийом, спосіб дії для досягнення чого-небудь або знаряддя (предмет, сукупність приладь) для здійснення певної діяльності ${ }^{1}$.

Відповідно до ч. 1 ст. 223 Кримінального процесуального кодексу України для отримання (збирання) доказів або перевірки вже отриманих доказів у конкретному кримінальному провадженні законодавець використовує такий засіб, як надання права вчиняти ту чи іншу слідчу (розшукову) дію. Р. С. Бєлкін також зазначає, що слідча дія є одним із криміналістичних засобів або методів роботи 3 доказами ${ }^{2}$. Отже, слідчі (розшукові) та негласні слідчі (розшукові) дії можна вважати різновидом пізнавальних тактикокриміналістичних засобів, які використовує слідчий під час здійснення досудового розслідування.

У юридичній літературі, зокрема криміналістичній, слідчі дії розглядають як процесуальну форму діяльності слідчого зі збирання фактичних даних (доказів), необхідних для розслідування злочинів, тобто як спосіб реалізації норм кримінально-процесуального законодавства. Однак окремі науковці правильно звертають увагу на те, що слідча дія в гносеологічному та методологічному планах $є$ засобом пізнання події злочину, осіб, які його вчинили, а також обставин кримінального провадження, тобто практичнопізнавальною діяльністю.

Так, на думку В. М. Стратонова, слідчі дії як способи отримання доказової інформації під час розслідування злочинів є основним засобом кримінально-процесуального пізнання. У результаті фундаментального дослідження теоретичних основ і практики пізнавальної діяльності слідчого вчений доходить висновку, що, незважаючи на існування нормативно-правового, етичного, управлінського, засвідчувального та інших аспектів слідчих дій, насамперед вони повинні розглядатись як інформаційно-пізнавальні моделі ${ }^{3}$. А. В. Яскевич також зазначає, що всі слідчі дії спрямовані на збирання й дослідження доказів, тобто забезпечують відшукання істини у встановленій законом процесуальній формі ${ }^{4}$. С. А. Шейфер, досліджуючи пізнавальну сутність слідчих дій, визначає їх як установлену законом сукупність пізнавальних прийомів, що застосовуються 3 метою одержання

\footnotetext{
${ }^{1}$ Див.: Ожегов С. И. Словарь русского языка/под ред. Н. Ю. Шведовой. М.: Рус. яз., 1983. С. 676.

${ }^{2}$ Белкин Р. С. Курс криминалистики: в 3 т. М.: Юристь, 1997. Т. 1. Общая теория криминалистики. 1997. С. 150.

3 Стратонов В. М. Теоретичні основи та практика пізнавальної діяльності слідчого: дис. ... д-ра юрид. наук: спец. 12.00.09. Херсон: Вид-во Херсон. держ. ун-ту, 2010. C. 167.

4 Яскевич A. В. Соотношение между следственными действиями и оперативнорозыскными мероприятиями. Проблемы криминалистики: сб. науч. трудов. Минск, 2003. Вып. 1. С. 154.
} 
доказової інформації. На його думку, слідчими є лише ті дії, що мають пізнавальний характер, і пов'язує їх зі словами «слід», «дослідження» ${ }^{1}$.

У межах слідчої (розшукової), негласної слідчої (розшукової) дії тактичні (пізнавальні) прийоми як засоби досягнення іії мети об'єднані у відповідну систему, що формує стадії діяльності слідчого та по суті утворює тактику слідчої дії. Зважаючи на цю систему, з криміналістичної точки зору слідчу дію доцільно розглядати як форму реалізації спеціальних методів, що використовує у своїй практичній діяльності слідчий для пізнання фактичних обставин злочину та встановлення істини в кримінальному провадженні. У слідчих (розшукових) діях, як у впорядкованій кримінально-процесуальним законом діяльності органу розслідування, знаходять практичну реалізацію пізнавальні прийоми та операції, за допомогою яких отримується необхідна інформація й передається адресатам доказування.

Слідчі (розшукові), негласні слідчі (розшукові) дії характеризуються: об'єктом пізнання; видом відомостей, на отримання яких спрямований цей засіб; тактичними комбінаціями зі збирання, дослідження, перевірки й оцінювання доказів; місцем, часом і послідовністю застосування цих прийомів і комбінацій тощо. Зазначені питання належать до змісту організаційнопізнавальної сторони слідчих (розшукових), негласних слідчих (розшукових) дій і не розглядаються в кримінально-процесуальному праві, проте $\epsilon$ предметом вивчення криміналістичної тактики. Тут потрібно звернути увагу на те, що пізнавальна й засвідчувальна сторони слідчої (розшукової), негласної слідчої (розшукової) дії органічно взаємопов'язані. Пізнавальні прийоми та операції підкріплюються й поєднуються з організаційно-розпорядчими діями, спрямованими на забезпечення правильності одержаних відомостей, повноту й точність їх передачі, охорону прав і законних інтересів осіб, що знаходяться у сфері дій зі збирання, дослідження й перевірки доказів.

Свого часу М. В. Салтевським була запропонована криміналістична класифікація слідчих дій, яка передбачала поділ цих засобів кримінально-процесуальної пізнавальної діяльності на три групи: нонвербальні, вербальні та змішані ${ }^{2}$. Нонвербальні слідчі дії спрямовані на отримання матеріально-фіксованих слідів. Вони засновані на прийомах безпосереднього почуттєвого, органолептичного пізнання об'єкта, таких як спостереження (виявлення), пошук, порівняння, вимірювання, опис тощо. До таких слідчих дій можна віднести огляд, обшук, виїмку, освідування. Вербальні слідчі дії дають можливість отримати інформацію, що може бути виражена словами. Основна пізнавальна сутність таких криміналістичних засобів полягає в одержанні усних і письмових повідомлень осіб, у свідомості яких відбиті певні відомості. Прикладом вербальних слідчих дій є допит, очна ставка, пред'явлення для впізнання. Змішані слідчі дії передбачають одночасне використання для одержання інформації як матеріальних об'єктів (речей), так і людей. До них належать слідчий експеримент, перевірка показань на місці, призначення експертизи.

${ }^{1}$ Шейфер C. А. Познавательное значение следственных действий и их систем. Вопросы борьбы с преступностью. 1972. Вып. 15. С. 64.

2 Салтевский $M$. В. Программа по советской криминалистике для высших учебных заведений МВД, осуществляющих подготовку специалистов на базе среднего специального образования. Київ: Лыбидь, 1999. 68 с. 
Зазначена класифікація способів збирання доказів, у якій окремі слідчі (розшукові) дії об'єднані у відповідні блоки та розглядаються як певні системи пізнавальних прийомів, дозволяє розмежувати різні за криміналістичною (пізнавальною) сутністю шляхи одержання інформації1.

Сутність будь-якої слідчої (розшукової), негласної слідчої (розшукової) дії в системі засобів збирання, дослідження, оцінювання й використання доказів під час кримінально-процесуальної діяльності визначається, насамперед, іiі тактичними можливостями забезпечення пізнавальних процесів і отриманням доказової інформації. Тому обрання процесуальною особою тієї чи іншої слідчої (розшукової) або негласної слідчої (розшукової) дії залежить від встановленого джерела інформації та різновиду відображення слідів, що мають чи можуть мати доказове значення. Розглядаючи слідчу (розшукову) або негласну слідчу (розшукову) дію як спеціальний засіб пізнання, потрібно розуміти, що кожна така дія завжди спрямована на збирання й перевірку не будь-якої інформації, а доказів, навіть якщо в її результаті докази не отримані.

Ще одним засобом отримання інформації в досудовому розслідуванні злочину є криміналістична техніка - сукупність приладів, апаратури, спорядження, методів і способів їх застосування². Забезпечення діяльності органів досудового розслідування, суду в напрямі встановлення істини в кримінальному провадженні найефективнішими й найсучаснішими засобами, що використовуватимуться винятково для розкриття, розслідування та попередження злочинів, $є$ головним завданням криміналістики ${ }^{3}$.

Спеціальні технічні засоби криміналістики - це науково обумовлені, перевірені експериментально й на практиці ефективні технічні засоби, які використовуються суб'єктами кримінально-процесуальної, експертної, оперативно-розшукової та адміністративної діяльності. До них відносять такі предмети, які є інструментами криміналістичної діяльності для збирання, дослідження й використання доказової інформації4. Отримані з їх допомогою дані застосовуються в пізнавальній діяльності для побудови версій, планування розслідування злочину. Зазначені засоби забезпечують швидке й повне розкриття обставин учиненого правопорушення, доведення винуватості осіб, які їх учинили, установлення інших обставин, шо є предметом доказування в кримінальному провадженні. У цьому полягає роль криміналістичної техніки як для досудового розслідування, так і судового розгляду кримінальних справ. Завдяки застосуванню техніко-криміналістичних засобів загалом підвищується ефективність протидії злочинності.

${ }^{1}$ Стратонов В. М. Криміналістична теорія пізнавальної діяльності: монографія. Херсон: Вид-во Херсон. держ. ун-ту, 2009. С. 99.

2 Іщсенко A. В., Матвієнко В. В. Криміналістичне забезпечення розслідування злочинів (постановка проблеми). Вісник ЗЮІ. 1998. № 2. С. 171.

${ }_{3}$ Яблоков Н. П. Криминалистика: учебник для вузов. М.: НОРМА-ИНФРА М, 2000. C. 32.

${ }^{4}$ Салтевський М. В. Криміналістика: підручник: у 2-х ч. Харків: Консум, Основа, 1999. Ч. 1. С. 66. 
Традиційна класифікація криміналістичної техніки виокремлює загальні технічні засоби, які запозичені з інших галузей науки й техніки та застосовуються без будь-яких змін і вдосконалень, наприклад, транспортні засоби, слюсарні або теслярські інструменти, засоби зв'язку, побутова фототехніка тощо. М. В. Салтевський пропонує не відносити останні до криміналістичних засобів, наголошуючи на їх загальному призначенні для використання в інших галузях діяльності. Разом із тим, якщо технічні засоби, запозичені з інших галузей знань, використовуються в криміналістиці у зв'язку з єдиним задумом і криміналістичною метою, їх можна називати засобами криміналістичної техніки ${ }^{1}$.

Ще одним поняттям, що виокремлює криміналістична наука, є «спеціальна техніка» - система приладів, пристроїв, матеріалів і речовин для збирання інформації негласними способами. Такі засоби використовуються при проведенні негласних слідчих (розшукових) дій. Вони зазвичай мають незначні габаритні розміри, замасковані під звичайні предмети обстановки, об'єкти особистої гігієни, знаряддя праці, одяг. Також це можуть бути автоматичні пристрої, які працюють в автономному режимі або управляються дистанційно. Спеціальна техніка виготовляється для конкретних цілей, завдань, виявлення предметів і документування осіб, подій тощо. Наприклад, операції негласного звукозапису, одержання дактилоскопічних слідів, нанесення міток на предмети, документи, одяг тощо вимагають технічної підготовки. Тому спеціальні пристрої, як правило, є унікальними. Разом із тим окремі екземпляри спеціальної техніки є стандартними й можуть бути предметами загальної криміналістичної техніки. Так, кишенькові диктофони, замасковані радіомікрофони та фотоапарати, розміщені на відповідних об’єктах маскування, стають засобами спеціальної техніки.

М. П. Яблоков, М. В. Салтевський, В. Ю. Шепітько наголошують на тому, що основним завданням криміналістичної техніки є виявлення й дослідження матеріальних слідів злочину з метою отримання відомостей про особу злочинця, використані предмети, умови їх застосування та інші обставини вчиненого злочинуㄹ․

Крім спеціальної криміналістичної техніки, до переліку засобів, що можуть використовуватися під час проведення негласних слідчих (розшукових) дій, законодавцем віднесено заздалегідь ідентифіковані (помічені) та несправжні (імітаційні) засоби. Відповідно до ст. 273 КПК України такі засоби можуть бути використані виключно для вирішення завдань кримінального провадження за рішенням керівника органу досудового розслідування, прокурора. Із цією метою допускається виготовлення та використання спеціально виготовлених речей і документів, створення спеціально утворених підприємств, установ, організацій. Коментуючи цю норму, фахівці в галузі кримінального-процесуального права визначають заздалегідь ідентифіковані (помічені) засоби як реальні матеріальні об'єкти, що мають

${ }^{1}$ Салтевський М. В. Криміналістика: підручник. С. 66.

2 Яблоков Н. П. Криминалистика: учебник. 2-е изд., перераб. и доп. М.: Юристъ, 2001. C. 170. 
індивідуальні ідентифікаційні ознаки (наприклад, серія та номер грошової купюри певного номіналу) або спеціально помічені (тобто на них нанесені певні позначки у зв'язку із проведенням негласної слідчої (розшукової) дії); несправжні (імітаційні) засоби - речі й документи, що повністю або частково мають ознаки та властивості матеріальних об'єктів, які вони заміщують, або спеціально утворені підприємства, установи, організації, що використовуються з метою проведення негласних слідчих (розшукових) дійํ․

Багато науковців і практиків у сфері протидії злочинності висловлюють думку, що основне призначення цих засобів полягає у створенні умов для негласного отримання певної інформації. Повністю поділяючи таку позицію, уважаємо, що заздалегідь ідентифіковані (помічені) та несправжні (імітаційні) засоби мають низку спільних рис із засобами криміналістичної техніки, зокрема, усі вони застосовуються з метою отримання доказів у кримінальному провадженні, тобто забезпечують пізнавальний процес, а результати та порядок їх використання мають бути процесуально закріплені в протоколі проведення слідчої (розшукової) або негласної слідчої (розшукової) дії.

Таким чином, результати проведеного дослідження дозволяють дійти висновку, що вирішення завдань кримінального процесу знаходиться в прямій залежності від криміналістичних засобів пізнавальної діяльності слідчого. Засоби кримінально-процесуального пізнання використовуються винятково для розкриття, розслідування й попередження злочинів і встановлення істини в кримінальному судочинстві. Проведення слідчих (розшукових), негласних слідчих (розшукових) дій, застосування криміналістичної техніки, заздалегідь ідентифікованих (помічених) і несправжніх (імітаційних) засобів мають на меті виявлення, фіксацію та дослідження будь-яких слідів кримінального правопорушення, пізнання яких має вирішальне значення для результатів досудового розслідування. Саме результати пізнавальної діяльності слідчого - отримання істинного знання про фактичні обставини вчиненого злочину, упливають на прийняття уповноваженим суб'єктом обгрунтованих кримінально-процесуальних рішень.

\section{СРЕДСТВА УГОЛОВНО-ПРОЦЕССУАЛЬНОГО ПОЗНАНИЯ}

\section{Ватраль А. В.}

Рассмотрены основные средства познавательной деятельности следователя в ходе досудебного расследования преступления. Определена роль следственньх (розыскных), негласных следственных (розыскных) действий, криминалистической техники и заранее идентифицированных (помеченных), ненастоящих (имитационных) средств в проиессе получения доказательственной информации для установления истины в уголовном производстве.

Ключевые слова: уголовно-процессуальное познание, доказывание, следственные (розыскные) действия, негласные следственные (розыскные) действия, криминалистическая техника, заранее идентифицированные (помеченные) средства, ненастоящие (имитационнье) средства.

1 Кримінальний процесуальний кодекс України: наук.-практ. коментар/за заг. ред. В. Г. Гончаренка, В. Т. Нора, М. С. Шумила. Київ: Юстініан, 2012. С. 443. 


\section{MEANS OF CRIMINAL PROCEDURAL COGNITION}

\section{Vatral A. .}

The paper deals with the basic means of investigator's cognition during investigation of a criminal offence. It was clarified that criminal procedural cognition as a process of knowledge formation on factual circumstances of the committed crime, unlike other kinds of human informative activity, occurs in the form of proving. The relationship of notions «knowledge» and "proving» was analyzed. It was proved that resolving tasks of the criminal process depends on criminalistics means of reception, analysis and estimation of the evidential information to which it's possible to refer investigative (search), covert investigative (search) actions and criminalistics technique, as well as identified (marked) and fake (imitating) means. The reason were given that investigative (search), covert investigative (search) actions in gnoseological and methodological plans are the means for cognition of crime event, persons who committed it, as well as the circumstances of criminal proceedings, that is, practical cognitive activity in the procedural form established by the law. The criminalistics technics as the set of devices, apparatus, equipments, gears, methods and ways of their use, has a number of common features with the means applied during covert investigatory (search) actions. The role of cognitive means which consists in revealing, recording and further investigation of the crime traces and also in creating conditions for necessary information receiving is defined. The data received with the help of special means, are used in criminal procedural informative activity for the construction of versions, planning of crime investigation with the aim to restore a reliable picture of the event occurred. There was paid attention that the true knowledge acquired in the course of pre-judicial investigation and judicial proceeding is decisive for their results because they allow to make well-founded criminally-procedural decisions on brining a guilty person to a responsibility for the committed crime.

Keywords: criminal procedural cognition, proving, investigative (search) actions, covert investigative (search) actions, criminalistics technique, identified (marked) means, fake (imitations) means. лістики Національного юридичного університету імені Ярослава Мудрого, кандидат юридичних наук, доцент, O. П. Білоус, здобувач Науково-дослідного інституту вивчення проблем злочинності імені академіка В. В. Сташиса НАПрН України

\section{ІННОВАЦІЙНІ ПІДХОДИ ДО ФІКСУВАННЯ ГРОШЕЙ ЯК РЕЧОВИХ ДОКАЗІВ У КРИМІНАЛЬНОМУ ПРОВАДЖЕННІ}

Розглянуто актуальні проблеми впровадження інноваційних технологій у діяльність із розслідування злочинів. Виходячи з аналізу стану фіксування органами досудового розслідування грошей, набутих кримінально проти-

(C) Білоус В. В., Білоус О. П., 2017 